\title{
SCREENING OF PLANT EXTRACTS USED IN TRADITIONAL ANTIDIARRHOEAL MEDICINES AGAINST PATHOGENIC ESCHERICHIA COLI
}

\author{
Jayshree D. Patel*, Devang K. Patel*, Anshu Shrivastava* and Vipin Kumar* \\ *Sadbhav SRISTI Sansodhan Laboratory, SRISTI, Gujarat University Area, Near Vijay Chaar Rasta \\ Navrangpura, Ahmedabad-380 009 INDIA.
}

\begin{abstract}
The petroleum ether, chloroform, methanol and aqueous extracts of Acacia catechu L. f. (bark), Acacia nilotica L. (bark), Aegle marmelos L. Correa. (fruit) Azadirachta indica L. (leaves), Annona squamosa L. (leaves), Trachyspermum ammi L. (seeds), Holarrhena antidysenterica L. (bark) and Ocimum basilicum L. (leaves) were tested against Enteropathogenic Escherichia coli (EPEC). These are the plants traditionally used by rural populace of semi arid regions of India for the treatment of diarrhoea. The ethnopharmacological information on the plants was collected by interviewing the traditional healers, community leaders and rural people of Gujarat State. The agar-well diffusion assay method was used to access the activities of plant extracts against the test organism. The results obtained show the strong activity of petroleum ether extract of $A$. marmelos, A. indica, T. ammi and H. antidysenterica; chloroform extract of A. catechu, A. indica and T. ammi; and methanol extract of A. catechu, A. nilotica, A. marmelos and T. ammi (MIC, d" $50 \mathrm{ì} \mathrm{g/ml)} \mathrm{followed} \mathrm{by} \mathrm{petroleum} \mathrm{ether} \mathrm{extract} \mathrm{of} O$. basilicum and chloroform extract of A. nilotica, A. marmelos and H. antidysenterica (MIC, 50-100 ì g/ml). These preliminary results will be helpful in rationalizing the use of plants based traditional medicines in modern systems of health care.
\end{abstract}

Key words: Medicinal plants; Herbal extracts; Traditional medicines; Escherichia coli.

\section{INTRODUCTION}

Diarrhoea disease caused by Enteropathogenic Escherichia coli (EPEC) are the major reasons of morbidity and mortality among children in the developing countries (Shoba and Thomas, 2001; Dean et al., 2006). This may be attributed to the increasing resistance of pathogen to the common antibiotics (Pinner et al., 1996; Senda et al., 1996; Archibald et al., 1997; Fridkin et al., 2002; Rajani et al., 2002) and their side effects (Krolczyk et al., 2004; Bombard et al., 2005). In recent years, special attention is being given on alternative safe natural bio-remedies to cure the infectious diseases because of their less or no side effects and resistance in microbes against them (Bonjar, 2004).

Many investigations proved the treatment and deterrence of gastrointestinal diseases using the plant extracts (Atta and Mouneir, 2004; Diehl et al., 2004). Owing to the support of national and international organizations for the studies on treatment and prevention of diarrhoeal diseases based on traditional practices, medicinal plants are becoming hopeful source of antidiarrhoeal drugs (Mukherjee et al., 1998; Tona et al., 1998; Otshudi et al., 2000a; Lin et al., 2002).

The people of India have a very long-standing tradition in the use of natural medicines and the local practices are still quite common in the treatment of diseases (Srinivasan et al., 2001; Harsha et al., 2002). The assessment of plants used in conventional medicines is anticipated to make available new antimicrobial agents (Otshudi et al., 2000b; Ryu et al., 2004). Thus, present study is aimed to investigate and establish the antidiarrhoeal potential of plant extracts used in folk medicine.

\section{MATERIALS AND METHODS}

\subsection{Medicinal plant materials}

Different ingredients (plant materials) were collected from their natural habitat (semi-arid regions of India), dried under shade and finally powdered using domestic grinder. The identity of plants was verified by the taxonomist at Botanical Survey of India, Arid Zone Circle, Jodhpur (India). Before the extraction, raw materials were pre-checked for pesticidal contaminations using suitable testing methods i.e. USP methods with GC-MS (data not given).

\subsection{Preparation of crude extracts}

\subsubsection{Preparation of water extract (decoction)}

Individual ingredient (20g) were subjected to boil in $200 \mathrm{ml}$ doubled distilled water in a $500 \mathrm{ml}$ flask till the total volume remained one fourth. The water extract was filtered through a 420 ìm stainless steel filter, cooled and transferred to screw caped glass vials.

\subsubsection{Organic solvent extraction}

Ingredients $(10 \mathrm{~g})$ were extracted with the solvents of different polarities (methanol, chloroform and petroleum ether) by cold maceration for 24 hrs. The extracts were filtered through Whatman No. 1 filter paper, which was impregnated with same solvent. The organic solvents were concentrated to near dryness using rotary evaporator bath under reduced pressure. The extracts were further diluted with Dimethylsulphoxide (DMSO) for experimentation. 


\subsection{Tested bacterial strain}

Bacterial strain Enteropathogenic Escherichia coli (EPEC) was selected as it is the most common pathogen, which cause diarrhoea. This attaches to and damages the small intestine (Laven, 2002). The pathogen was cultured on nutrient agar media (HiMedia MM012). Extracts of all the herbal ingredients were screened against Escherichia coli. Bacterial strain was procured from patient suffering from gastrointestinal problem. All the chemicals were of analytical reagent grade (EMerck).

\subsection{Determination of antibacterial activity}

\subsubsection{Preparation of inoculums}

Bacteria were grown to lag phase before inoculated in to liquid broth medium for activation, the composition of which is as per the Indian Pharmacopoeia (1996) and incubated for 24 hours (Dykes et al., 2003). For all the experiments $0.1 \mathrm{ml}$ cultures were inoculated in $10 \mathrm{ml}$ broths giving final cell load of $10^{6}-10^{7} \mathrm{CFU} / \mathrm{ml}$ in nutrient broth media (Musumeci et al., 2003; Sohn et al., 2004).

\subsubsection{Testing of antibacterial activity}

\subsubsection{Agar well diffusion assay method}

A $0.5 \mathrm{ml}$ volume of the standard inoculum $\left(10^{6}-10^{7} \mathrm{CFU}\right)$ of the test bacterial strain was spread on Mueller Hinton Agar (MHA) with a sterile bent glass rod spreader and allowed to dry. Then, $6 \mathrm{~mm}$-diameter wells were bored in the MHA. Plant extracts (1000, 500, 100 and $50 \mathrm{ì} \mathrm{g/ml} \mathrm{concentration)} \mathrm{were} \mathrm{introduced}$ into each well and allowed to stand for $1 \mathrm{~h}$ at room temperature to diffuse before incubation at $37^{\circ} \mathrm{C}$ for $24 \mathrm{~h}$. The inhibition zone diameter (IZD) was measured by antibiotic zone reader to nearest mm (Okoli and Iroegbu, 2004).

\subsubsection{Total plate count agar method}

To determine the number of the viable bacteria, $0.1 \mathrm{ml}$ of the suspension mixture from plant extracts and bacteria were used for re-plate on Muller-Hinton agar plates. The samples were diluted with $0.85 \%$ normal saline solution to an appropriate concentration which gave a countable number of the colonies/plate. $0.1 \mathrm{ml}$ of the diluted samples were spread on MullerHinton agar plate and incubated further for $18-24 \mathrm{~h}$. at $37^{\circ} \mathrm{C}$ in biological incubator (Wongkham et al., 2001).

\subsubsection{Determination of minimum inhibitory concentration (MIC)}

Minimum inhibitory concentrations (MICs) were determined using agar well diffusion assay method as described by Mendoza (1998).

\section{RESULTS AND DISCUSSION}

The results for the antimicrobial activities of different plant extracts in agar well diffusion assay method and total plate count agar method are presented in Table 1 and 2 respectively. In agar well diffusion assay method (Table 1), methanol extracts of A. catechu, A. nilotica, A. marmelos, T. ammi and $H$. antidysenterica; chloroform extracts of $A$. catechu, $A$. in- dica and T. ammi, and petroleum ether extracts of A. marmelos, A. indica, and T. ammi showed highest inhibition and the activities were reported at the concentration of $50 \mathrm{ì} \mathrm{g/ml.} \mathrm{Chlo-}$ roform extracts of A. nilotica, A. marmelos and $H$. antidysenterica, and petroleum ether extract of $O$. basilicum were found active at the concentration of $100 \mathrm{ì} \mathrm{g/ml.} \mathrm{Aqueous}$ and petroleum ether extracts of A. nilotica; chloroform and petroleum ether extracts of $A$. squamosa, and methanol and chloroform extracts of $O$. basilicum inhibited the pathogen at the concentration of $500 \mathrm{ì} \mathrm{g/ml,} \mathrm{while,} \mathrm{little} \mathrm{inhibition} \mathrm{at} \mathrm{the}$ concentration of $1000 \mathrm{ì} \mathrm{g/ml} \mathrm{was} \mathrm{also} \mathrm{shown} \mathrm{by} \mathrm{methanol}$ extract of $H$. antidysenterica. No visible growth inhibition of $E$. coli was observed during the screening of rest of the extracts at any of the studied concentration.

Results (Table 2) of antimicrobial activity of the different extracts at a concentration of $1000 \mathrm{ì} \mathrm{g/ml} \mathrm{using} \mathrm{total} \mathrm{plate} \mathrm{count}$ agar method revealed a high inhibition of $E$. coli growth by methanol extracts of $A$. catechu, $A$. indica, and T. ammi; chloroform extracts of $A$. marmelos and $A$. indica, and petroleum ether extracts of $A$. indica and $O$. basilicum. Moderate inhibition in the growth of $E$. coli by methanol extracts of $A$. nilotica, $H$. antidysenterica and $O$. basilicum; chloroform extract of $O$. basilicum, and petroleum ether extracts of A. marmelos and $H$. antidysenterica was observed. Little inhibition in the growth of pathogen was also observed in the plates containing aqueous extracts of $A$. nilotica and $O$. basilicum; methanol extract of $A$. squamosa; chloroform extracts of $A$. nilotica, T. ammi and $H$. antidysenterica, and petroleum ether extract of T. ammi. Rest of the extracts showed no inhibition in microbial growth, when screened against studied strain of E. coli.

Plants used in traditional Indian system of medicine have been found active against a wide variety of microorganisms (Khan et al., 1994; Ahmad et al., 1998; Ahmad and Beg, 2001). Many biochemical constituents of plants have been shown to possess excellent biological activities (Gupta et al., 1993; Cowan, 1999; Iwu et al., 1999; Ogunleye and Ibitoye, 2003; Tshikalange et al., 2005). Although, the reports on the use of studied plants viz. Acacia catechu (Felter and Lloyd, 1998), Acacia nilotica (Sawhney et al., 1978; Agunu et al., 2005), Aegle marmelos (Shrivastava, 1985; Dhuley, 2003; Rao et al, 2003; Mazumder et al., 2006), Annona squamosa (Santos and Santana, 2001), Azadirachta indica (Singh, 1986; Bhattarai, 1993), Trachyspermum ammi (Devasankaraiah et al., 1974; Singh, 1986), Holarrhena antidysenterica (Kavitha et al., 2004) and Ocimum basilicum (Geeta et al., 2001) for the treatment of diarrhoea are available but we found contradictory and equivocal reports on screening of their extracts against $E$. coli in the literature. The aqueous and ethanolic extracts of Acacia catechu and Holarrhena antidysenterica (Voravuthikunchai et al., 2004), Acacia nilotica (Jain et al., 1987), Azadirachta indica (Talwar et al., 1997), Trachyspermum ammi (Ray and Majumdar, 1976; Damle and Tipnis, 1980); chloroform extract of Aegle marmelos (Mazumder et al., 2006) and Annona squamosa (Adoum et al., 1997); seed oil (0.4\%) of Aegle marmelos (Singh et al., 1983); and essential oil of Ocimum basilicum (Farouk et al., 1983; Janssen et al., 1986; Srinivasan et al., 2001) demonstrated antibacterial activities, while, aqueous 
Table 1: Antimicrobial activity of plant extracts against Escherichia coli agar well diffusion assay method (n=3)

\begin{tabular}{|l|c|c|c|c|}
\hline \multirow{2}{*}{ Plant name } & \multicolumn{4}{|c|}{ Extract type } \\
\cline { 2 - 5 } & Aqueous* & Methanol* & Chloroform* & Petroleum ether* \\
\hline Acacia catechu & $--(30)$ & $++++(60)$ & $++++(320)$ & $--(>1000)$ \\
\hline Acacia nilotica & $++(120)$ & $++++(70)$ & $+++(200)$ & $++(140)$ \\
\hline Aegle marmelos & $--(>1000)$ & $++++(<50)$ & $+++(160)$ & $++++(100)$ \\
\hline Azadirachta indica & $--(>1000)$ & $--(>1000)$ & $++++(30)$ & $++++(110)$ \\
\hline Annona squamosa & $--(>1000)$ & $--(>1000)$ & $++(220)$ & $++(160)$ \\
\hline Trachyspermum ammi & $--(>1000)$ & $++++(70)$ & $++++(40)$ & $++++(240)$ \\
\hline Holarrhena antidysenterica & $--(>1000)$ & $+(180)$ & $+(>1000)$ & $++++(50)$ \\
\hline Ocimum basilicum & $--(>1000)$ & $++(100)$ & $++(70)$ & $+++(80)$ \\
\hline
\end{tabular}

-, No inhibition; ++++, Inhibition at 50 ì g/ml; +++, Inhibition at $100 \mathrm{ìg} / \mathrm{ml} ;++$, Inhibition at $500 \mathrm{ìg} / \mathrm{ml}$; +, Inhibition at $1000 \mathrm{ìg}$ /ml. *The different value of MIC in ì $\mathrm{g} / \mathrm{ml}$; is given in the parenthesis.

Table 2: Plate count of bacteria incubated in agar from the broth containing plant extracts for 24 hrs (n=3)

\begin{tabular}{|l|c|c|c|c|}
\hline \multirow{2}{*}{ Plant name } & \multicolumn{4}{|c|}{ Extract type } \\
\cline { 2 - 5 } & Aqueous & Methanol & Chloroform & Petroleum ether \\
\hline Acacia catechu & ++++ & + & ++++ & ++++ \\
\hline Acacia nilotica & +++ & ++ & +++ & ++++ \\
\hline Aegle marmelos & ++++ & ++++ & + & ++ \\
\hline Azadirachta indica & ++++ & + & + & + \\
\hline Annona squamosa & ++++ & +++ & +++ & +++ \\
\hline Trachyspermum ammi & ++++ & + & +++ \\
\hline Holarrhena antidysenterica & ++++ & ++ & ++ \\
\hline Ocimum basilicum & \multicolumn{2}{|c|}{+++} & ++ \\
\hline
\end{tabular}

++++, > 500 X $10^{5} \mathrm{CFU} / \mathrm{ml}$; +++, 200-500 X $10^{5} \mathrm{CFU} / \mathrm{ml}$; ++, 50-200 X $10^{5} \mathrm{CFU} / \mathrm{ml}$; +, < 50 X $10^{5} \mathrm{CFU} / \mathrm{ml}$; -, No growth

extracts of all the studied plants reported equivocal and/or inactive by various researchers (Gupta et al., 1993; Ahmad et al., 1998; Chariandy et al., 1999; Ali et al., 2001). Alzoreky and Nakahara (2003) reported acetone and buffered methanol extracts of Azadirachta indica and Ocimum basilicum inactive against $E$. coli. We also got similar and/or contrast results with the findings of earlier research.

In present study, one or more organic extracts of each plant except $A$. squamosa were able to inhibit the growth of tested standard strain of pathogen to a certain extent at $100 \mathrm{ì} \mathrm{g/ml}$ that corresponds to $50-200 \times 10^{5} \mathrm{CFU} / \mathrm{ml}$ in total plate count agar method. In case of $A$. squamosa, inhibition of microbial growth was recorded at $500 \mathrm{ì} \mathrm{g} / \mathrm{ml}$ concentration. The highest activity was shown by methanol extracts of $A$. nilotica and $T$. ammi, and petroleum ether extract of $A$. indica. A number of explanations can be given for the difference in biological activity reports of some common extracts against same or similar microorganism, but the first logic is dissimilarities in phytochemicals of similar plants growing at different geographical locations (Olila et al., 2001). In the findings, there were marked differences at few places in the activities of some extracts in two antimicrobial testing methods. The variation in results during the antimicrobial efficacy in different testing methods of a compound transpires because of effect of medium and supplements (Jones, 1996), temperature and other inoculation conditions (Michel and Blanc, 1994), molecular weight and diffusion rate of compound through medium (Marshall et al., 1999; Olila et al., 2001) etc.

The results of present study indicate that plant extracts showing positive microbial activity provide the scientific base to include the traditional practices in modern system of medicines. They may, therefore, provide new leads in the development of new antimicrobial drugs for the therapy of diarrhoea and other infectious diseases caused by E. coli.

\section{ACKNOWLEDGEMENT}

The authors wish to extend their sincere thanks to scouts and collaborators of Honey Bee Network for scouting, verification and documentation of traditional practices. Financial support for this research was provided by Sadbhav Foundation, Mumbai and DSIR (MOST), New Delhi. 


\section{REFERENCES}

Adoum, O.A., Dabo, N.T., Fatope, M.O. 1997. Bioactivities of some savanna plants in the brine shrimp lethality test and in vitro antimicrobial assay. International Journal of Pharmacognocy 35(5): 334-337.

Agunu, A., Yusuf, S., Andrew, G.O., Zezi, A.U., et al. 2005. Evaluation of five medicinal plants used in diarrhoea treatment in Nigeria. Journal of Ethnopharmacology 101(1-3): 27-30.

Ahmad, I., Beg, A.Z. 2001. Antimicrobial and phytochemiacl studies on 45 Indian medicinal plants against multi-drug resistant human pathogens. Journal of Ethnopharmacology 74: 113-123.

Ahmad, I., Mehmood, Z., Mohammad, F. 1998. Screening of some Indian medicinal plants for their antimicrobial properties. Journal of Ethnopharmacology 62: 183-193.

Ali, M.S., Azhar, I., Ahmad, F., Ahmad, V.U., et al. 2001. Antimicrobial screening of mimoaceous plants. Pharmaceutical Biology 39(1): 43-46.

Alzoreky, N.S., Nakahara, K. 2003. Antibacterial activity of extracts from some edible plants commonly consumed in Asia. International Journal of Food Microbiology 80(3): 223-230.

Archibald, L.K., Manning, M.L., Bell, L.M., Banerjee, S., Jarvis, W.R 1997. Patient density, nurse-to-patient ratio and nosocomial infection risk in a pediatric cardiac intensive care unit. The Pediatric Infectious Disease Journal 16(11): 1045-1048.

Atta, A.H., Mouneir, S.M. 2004. Antidiarrhoeal activity of some Egyptian medicinal plant extracts. Journal of Ethnopharmacology 92: 303-309.

Bhattarai, N.K. 1993. Folk herbal remedies fro diarrhoea and dysentery in central Nepal. Fitoterapia 64(3): 243-250.

Bombard, F., Campo, P., Lataye, R. 2005. Combined effects of noise and gentamicin on hearing in the guinea pig. Noise and Health 7(28): 29-39.

Bonjar, S. 2004. Evaluation of antibacterial properties of some medicinal plants used in Iran. Journal of Ethnopharmacology 94(2-3): 301-305.

Chariandy, C.M., Seaforth, C.E., Phelps, R.H., Pollard, G.V., et al. 1999. Screening of medicinal plants from Trinidad and Tobago for antimicrobial and insecticidal properties. Journal of Ethnopharmacology 64(3): 265-270.

Cowan, M.M. 1999. Plant Products as Antimicrobial Agents. Clinical Microbiological Review 12(4): 564-582.

Damle, A.V., Tipnis, H.P. 1980. Chemical and antimicrobial investigation of callus culture of Trachyspermum ammi sprague(ajowan). Indian Journal of Pharmaceutical Science 42: 86-87.

Dean, P., Maresca, M., Schuller, S., Phillips, A.D., et al. 2006. Potent diarrhoeagenic mechanism mediated by the cooperative action of three enteropathogenic Escherichia coli-injected effector proteins. Proceedings of the National Academy of Sciences 103(6): 1876-1881.

Devasankaraiah, G., Hanin, I., Aranath, P.S.R.K., Ramanamurthy, P.S.V. 1974. Cholinomimetic effects of aqueous extracts from Carum copticum seeds. British Journal Pharmacology 52: 613-614.

Dhuley, J.N. 2003. Investigation on the gastroprotective and antidiarrhoeal properties of Aegle marmelos unripe fruit extract. Hindustan Antibiotic Bulletin 45-46(1-4): 41-46.

Diehl, M.S., Atindehou, K.K., Tere, H., Betschart, B. 2004. Prospect for anthelminthic plants in the Ivory Coast using ethnobotanical criteria. Journal of Ethnopharmacology 95: 277-284.
Dykes, G. A., Amarowicz, R., Pegg, R.B. 2003. Enhancement of nisin antibacterial activity by a bearberry (Arctostaphylos uva-ursi) leaf extract. Food Microbiology 20: 211-216.

Farouk, A., Bashir, A.K., Salih, A.K.M. 1983. Antimicrobial activity of certain Sudanese plants used in folkloric medicine. Screening for antibacterial activity (i). Fitoterapia 54(1): 3-7.

Felter, H.W., Lloyd, J.U. 1998. King’s American Dispensatory. http:/ /www.henriettesherbal.com/eclectic/kings/acacia-cate.html (Visited March 11, 2006).

Fridkin, S.K., Lawton, R., Edwards, J.R., Tenover, F.C., McGowan, J.E. Jr, Gaynes, R.P. 2002. Monitoring antimicrobial use and resistance: comparison with a national benchmark on reducing vancomycin use and vancomycin-resistant enterococci. Emerging Infectious Diseases 8(7): 702-707.

Geeta, Vasudevan, D.M., Kedlaya, R., Deepa, S., Ballal, M. 2001. Activity of Ocimum sanctum (the traditional Indian medicinal plant) against the enteric pathogens. Indian Journal of Medical Sciences 55(8): 434-438.

Gupta, S., Yadava, J.N.S., Tandon, J.S. 1993. Antiscretory (antidiarrhoeal) activity of Indian medicinal plants against Escherichia coli enterotoxin-induced secretion in rabbit and guinea pig ileal loop models. International Journal of Pharmacology 31(3): 198-204.

Harsha, V.H., Hebbar, S.S., Hegde, G.R., Shripathi, V. 2002. Ethnomedical knowledge of plants used by Kunabi Tribe of Karnataka in India. Fitoterapia 73: 281-287.

Indian pharmacopoeia. 1996. Test for specified microorganisms. Volume II. The controller of publications, New Delhi, p. A-115.

Iwu, M.M., Duncan, A.R., Okunji, C.O. 1999. New antimicrobials from plant origin. J. janick (ed.), ASHS Press, Alexandria, VA, p. 457-462.

Jain, A.K., Shimoi, K., Nakamura, Y., Tomita, I., et al. 1987. Preliminary study on the desmutagenic and antimutagenic effect of some natural products. Current Science 56(24): 1266-1269.

Janssen, A.M., Chin, N.L.J., Scheffer, J.J.C., Baerheim-svendsen, A. 1986. Screening for antimicrobial activity of some essential oils by the agar overlay technique. Pharmaceutisch Weekblad Scientific Edition.8(6): 289-292.

Jones, R.N. 1996. Medium and supplement effects on the antimicrobial activity of quinupristin/dalfopristin tested by agar dilution and etest methods. Diagnostic Microbiology and Infectious Disease 26(2): 99-102.

Kavitha, D., Shilpa, P.N., Devaraj, S.N. 2004. Antibacterial and antidiarrhoeal effects of alkaloids of Holarrhena antidysenterica WALL. Indian Journal of Experimental Biology 42(6): 589-594.

Khan, M.A., Khan, T., Ahmad, Z. 1994. Barks used as source of medicine in Madhya Pradesh, India. Fitoterapia 65(5): 444-446.

Krolczyk, G., Czupryna, A., Sobocki, J., Nowak, L., et al. 2004. Effect of bowel decontamination with metronidazole and vancomycin on gastroduodenal myoelectric activity. Folia Medica Cracoviensia 45(3-4): 45-53.

Laven, R. 2002. NADIS Cattle Disease Focus. http:// www.mdcfmp.org.uk/uploadeddocuments / Disease/ Displaced\%20Abomasum.pdf (Site visited on January 20, 2006)

Lin, J., Puckree, T., Mvelase, T.P. 2002. Anti-diarrhoeal evaluation of some medicinal plants used by Zulu traditional healers. Journal of Ethnopharmacology 79: 53-56.

Marshall, S.A., Jones, R.N., Erwin, M.E., the Quality Control Study Group. 1999. Antimicrobial activity of SCH27899 (Ziracin ${ }^{\circledR}$ ), a 
novel everninomicin derivative, tested against Streptococcus spp.: disk diffusion / Etest method evaluations and quality control guidelines. Diagnostic Microbiology and Infectious Disease 33(1): 19-25.

Mazumder, R., Bhattacharya, S., Mazumder, A., Pattnaik, A.K., Tiwary, P.M., Chaudhary, S. 2006. Antidiarrhoeal evaluation of Aegle Marmelos (Correa) Linn. root extract. Phytotherapy Research 20(1): 82-84.

Mendoza, M.T. 1998. What's new in antimicrobial susceptibility testing?. The Philippine Journal of Microbiology and Infectious Diseases 27(3): 113-115.

Michel, C., Blanc, G., 1994. Bacterial resistance to antimicrobial agents used in fish farming: A critical evaluation of method and meaning. Annual Review of Fish Diseases 4: 273-313.

Mukherjee, P.K., Saha, K., Murugesan, T., Mandal, S.C., et al. 1998. Screening of anti-diarrhoeal profile of some plant extracts of a specific region of West Bengal, India. Journal of Ethnopharmacology 60: 85-89.

Musumeci, R., Speciale, A., Costanzo, R., Annino, A., et al. 2003. Berberis aetnensis C. Presl. extracts: antimicrobial properties and interaction with ciprofloxacin. International Journal of Antimicrobial Agents 22(1): 48-53.

Ogunleye, D.S., Ibitoye, S.F. 2003. Studies of antimicrobial activity and chemical constituents of Ximenia Americana. Tropical Journal of Pharmaceutical Research 2(2): 239-241.

Okoli, A.S., Iroegbu, C.U. 2004. Evaluation of extracts of Anthocleista djalonensis, Nauclea latifolia and Uvaria afzalii for activity against bacterial isolates from cases of non-gonococcal urethritis. Journal of Ethnopharmacology 92(1): 135-144.

Olila, D., Odyek, O., Asibo, O.J. 2001. Antibacterial and antifungal activities of extracts of Zanthoxylum chalybeum and Warburgia ugandensis, Ugandan medicinal plants. African Health Sciences 1(2): 66-72.

Otshudi, A.L., Vercruysse, A., Foriers, A. 2000a. Contribution to the ethnobotanical, phytochemical and pharmacological studies of traditionally used medicinal plants in the treatment of dysentery and diarrhoea in Lomela area, Democratic Republic of Congo (DRC). Journal of Ethnopharmacology 71: 411-423.

Otshudi, A.L., Vercruysse, A., Foriers, A. 2000b. Antidiarrhoeal activity of root extracts from Roureopsis obliquifoliolata and Epinetrum villosum. Fitoterapia. 72: 291-294.

Pinner, R.W., Teutsch, S.M., Simonsen, L., Klug, L.A., Graber, J.M., Clarke, M.J., Berkelman, R.L. 1996. Trends in infectious diseases mortality in the United States. The Journal of the American Medical Association 275(3): 189-193.

Rajani, M., Saxena, N., Ravishankara, N.M., Desai, N., Padh, H. 2002. Evaluation of the antimicrobial activity of ammoniacum gum from Dorema ammoniacum. Pharmaceutical Biology 40(7): 534-541.

Rao, C.V., Amresh, R.K., Irfan, A., Rawat, A.K.S., Pushpangadan, P. 2003. Protective effect of Aegle marmelos fruit in gastrointestinal dysfunction in rats. Pharmaceutical Biology 41(8): 558-563.

Ray, P.G., Majumdar, S.K. 1976. Antimicrobial activity of some Indian plants. Economic Botany 30: 317-320.
Ryu, S., Park, C., Baek, H., Baek, S., et al. 2004. Anti-diarrhoeal and spasmolytic activities and acute toxicity study of Soonkijangquebo, a herbal anti-diarrhoeal formula. Journal of Ethnopharmacology 91: 75-80.

Santos, A.F.D., Santana, A.E.G. 2001. Molluscicidal properties of some species of Annoa. Phytomedicine 8(2): 115-120.

Sawhney, A.N., Khan, M.R., Ndaalio, G., Nkunya, M.H.H., Wevers, H. 1978. Studies on the rationale of African traditional medicine. Part ii. Preliminary screening of medicinal plants for anti-gonoccoci activity. Pakistan Journal of Scientific and Industrial Research 21(5/ 6): 189-192.

Senda, K., Arakawa, Y., Ichiyama, S., Nakashima, K., et al. 1996. PCR detection of metallo-beta-lactamase gene (blaIMP) in gram-negative rods resistant to broad-spectrum beta-lactams. European Journal of Clinical Microbiology 34(12): 2909-2913.

Shoba, F.G., Thomas, M. 2001. Study of antidiarrhoeal activity of four medicinal plants in castor-oil induced diarrhoea. Journal of Ethnopharmacology 76: 73-76.

Shrivastava, R.K., 1985. Aegle marmelos: an Ipso Facto plant of India. Journal of Research and Education in Indian Medicine 4(3/4): 21-25.

Singh, K.V., Bhatt, S.K., Sthapak, J.K. 1983. Antimicrobial and anthelmintic properties of the seeds of Aegle marmelos. Fitoterapia 54(6): 261-264.

Singh, Y.N. 1986. Traditional medicine in Fiji: some herbal folk cures used by Fiji Indians. Journal of Ethnopharmacology 15(1): 57-88.

Sohn, H.Y., Son, K.H., Kwon, C.S., Kwon, G.S., et al. 2004. Antimicrobial and cytotoxic activity of 18 prenylated flavonoids isolated from medicinal plants: Morus alba L., Morus mongolica Schneider, Broussnetia papyrifera (L.) Vent, Sophora flavescens Ait and Echinosophora koreensis Nakai. Phytomedicine 11(7-8): 666-672.

Srinivasan, D., Nathan, S., Suresh, T., Perumalsamy, P.L. 2001. Antimicrobial activity of certain Indian medicinal plants used in folkloric medicine. Journal of Ethnopharmacology 74: 217-220.

Talwar, G.P., Raghuvanshi, P., Misra, R., Mukherjee, S., et al. 1997. Plant immunomodulators for termination of unwanted regnancy and for contraception and reproductive health. Immunology and Cell Biolology 75(2): 190-192.

Tona, L., Kambu, K., Ngimbi, N., Cimanga, K., et al. 1998. Antiamoebic and phytochemical screening of some Congolese medicinal plants. Journal of Ethnopharmacology 61: 57-65.

Tshikalange, T.E., Meyer, J.J., Hussein, A.A. 2005. Antimicrobial activity, toxicity and the isolation of a bioactive compound from plants used to treat sexually transmitted diseases. Journal of Ethnopharmacology 96(3): 515-9.

Voravuthikunchai, S., Lortheeranuwat, A., Jeeju, W., Sririrak, T., et al. 2004. Effective medicinal plants against enterohaemorrhagic Escherichia coli O157:H7. Journal of Ethnopharmacology 94(1): 49-54.

Wongkham, S., Laupattarakasaem, P., Pienthaweechai, K., Areejitranusorn, P., et al. 2001. Antimicrobial activity of Streblus asper leaf extract. Phytotherapy Research 15: 119-121. 